\title{
Control of the amount and functionality of the eEF1A1 and eEF1A2 isoforms in mammalian cells
}

\author{
B. S. Negrutskii ${ }^{1}$, O. V. Novosylna ${ }^{1}$, L.V. Porubleva ${ }^{1}$, A. A. Vislovukh ${ }^{2}$ \\ ${ }^{1}$ Institute of Molecular Biology and Genetics, NAS of Ukraine \\ 150, Akademika Zabolotnoho Str., Kyiv, Ukraine, 03143 \\ ${ }^{2}$ British Columbia Cancer Research Centre, \\ 675 West 10th Avenue, Vancouver, BC, V5Z 1L3, Canada \\ negrutskii@imbg.org.ua
}

\begin{abstract}
Aim. To review mechanisms of regulation of expression and the functionality of two isoforms of translation elongation factor eEF1A in mammalian cells. Results. eEF1A1 and eEF1A2 proteins are regulated by post-translational modifications, protein-protein and protein-tRNA interactions as well as by controlling the amount of their mRNAs in human cells. Conclusions. EEF1A1 mRNA levels in cancer cells may depend on the allelic copy number while the level of EEF1A2 mRNA may be controlled by micro RNAs. eEF1A2 protein activity in different cellular processes may be determined, in part, by its increased affinity for tRNA and viral RNAs as compared to eEF1A1. eEF1A1 activity can be regulated by its increased susceptibility to post-translational modifications (PTM) and protein-protein interactions (PTI) as compared to eEF1A2.
\end{abstract}

Ke y w ord s: Translation elongation factors, regulation, protein isoforms

Two tissue specific isoforms of translation elongation factor $1 \mathrm{~A}$ (eEF1A1 and eEF1A2), with mutually exclusive expression, provide efficient delivery and binding of aminoacyltRNA to 80 S ribosomes [1]. eEF1A2 functions in neurons, myocytes, cardiomyocytes and some other highly specialized cells while eEF1A1 contributes to mRNA translation in all other tissues of Mammalia [2].

A number of non-translational processes involving eEF1A are described suggesting that, due to its high abundancy, eEF1A may serve as an important hub protein which connects different cellular activities [3]. It contributes to cell cycle progression [4], chaperon-mediated autophagy [5], apoptosis [6], lypotoxic cell death [7], protein renaturation [8], endogenous proteolysis [9], lysosome biogenesis [10], spermatogenesis [11] and multiple cytoskeleton rearrangements [12-14].

Normally the expression of eEF1A2 in the organism is restricted by a small number of

(C) 2018 B. S. Negrutskii et al.; Published by the Institute of Molecular Biology and Genetics, NAS of Ukraine on behalf of Biopolymers and Cell. This is an Open Access article distributed under the terms of the Creative Commons Attribution License (http://creativecommons.org/licenses/by/4.0/), which permits unrestricted reuse, distribution, and reproduction in any medium, provided the original work is properly cited 
tissues, however, the appearance of this isoform was registered in the cancer tissues of different localization [15]. In some cases, such as ovary cancer, the proofs of its true oncogenic action have been obtained [16, 17]. Contrary to this, conflicting information is present on the cancer links of the eEF1A1 isoform [18, 19].

Because of proto-oncogenic features of eEF1A2, its tissue specific expression should be precisely maintained. In addition, the control of the eEF1A1 and eEF1A2 functioning is implemented at the protein level as well. The ways how the organism exercises such regulation are mostly unknown. The isoformspecific ways of control are involved in specifically inducing/inhibiting expression and/or functioning of eEF1A1 or eEF1A2. This review is focused on several possibilities to control the amount and activity of the isoforms in some translational and non-translational processes at the post-transcriptional and protein levels. The potential regulation mechanisms involving microRNA, post-translational modifications (PTM), protein-protein interaction (PPI) and interaction with RNA are discussed.

\section{Regulation of EEF1A1 and EEF1A2 mRNA}

Regulation of the amount of eEF1A1 and eEF1A2 isoforms in cells can be performed at the transcriptional and post-transcriptional levels. The proteins eEF1A1 and eEF1A2 are similarly stable in mammalian cells [20] so the specifically accelerated degradation of one isoform is highly unlikely. On the contrary, the mRNAs coding eEF1A1 or eEF1A2 show quite different half-lives [20] suggesting the control of eEF1A mRNAs stability could be among the important regulatory factors for the eEF1A proteins. Based on the bioinformatics analysis we have suggested that the post-transcriptional regulation of the eEF1A2 expression could be microRNA-mediated [21] and predicted that the microRNAs which may specifically target 3'UTR of eEF1A2 mRNA, could be important regulators of eEF1A2 in cancer progression and during myoblast differentiation [22]. Subsequently, an experimental evidence to the role of microRNAs in the cancer-related elevation of the eEF1A2 level has been obtained [23].

Among four predicted high-scored microRNAs, the two, miR-663 and miR-744, have been shown to be positive in luciferase test specifically targeting the 3'UTR of eEF1A2 mRNA. Importantly, no cooperative action of these miRNAs on EEF1A2 mRNA has been observed. Then, the actual microRNA binding sites were identified in 3'UTR EEF1A2 by combination of bioinformatics and mutational analysis.

Subsequent experiments were conducted using human breast cancer cell line MCF7. The addition of extra amounts of these microRNAs to MCF7 cells inhibited the level of EEF1A2 mRNA by 30-50\%. Even more importantly, an increase in miR-663 and miR-744 amount caused a significant reduction of the amount of the eEF1A2 protein. The addition of siRNA directed to EEF1A2 mRNA led to the effect similar to the effects induced by the micro RNAs supporting EEF1A2 mRNA as a target of miR-663 and miR-744.

At the cellular level, addition of miR-663 and miR-744 had a negative effect on proliferation of MCF7 cells. Similar effect was observed after treatment of MCF7 cells with the 
anti-eEF1A2 siRNA, suggesting that anti-proliferative effect of micro RNAs was achieved due to targeting EEF1A2 [23].

Thus, we have shown that microRNA-mediated control can indeed contribute to the regulation of the eEF1A2 amount in cancer cells. The eEF1A2-based mechanism of the inhibition of cancer growth by the same microRNAs has been recently confirmed for pancreatic cancer as well [24]. However, one should keep in mind that EEF1A2 is not the only target of these microRNAs. The novel miR-663 targets are transforming growth factor- $\beta 1$ [25], proteins PUMA/BBC3 and BTG2 [26], cyclin-dependent kinase inhibitor 2A [27]. The novel miR-744 targets are nuclear factor I X (NFIX) and heterogeneous nuclear ribonucleoprotein C (HNRNPC) [28], oncogene Notch1 [29], matrix metallopeptidase 9 (MMP-9) [30]. As these targets are also related to the cancer development, one cannot be absolutely sure that targeting eEF1A2 is the only mechanism of anti-cancer action of these microRNAs. However, the role of microRNAs in the control of eEF1A2 amount in cells at post-transcriptional level is considered to be proved by now.

On the contrary, an amount of eEF1A1 mRNA in breast cancer is significantly decreased [18]. It was noticed that the EEF1A1 mRNA expression declines with tumor invasion, dissemination to lymph nodes, at advanced stage and post-menopause. It was concluded that the low EEF1A1 mRNA expression could be an independent marker for poor prognosis of ER+ breast cancer. It was shown that under-expression of the EEF1A1 mRNA was not related to the promotor hypermethylation or EEF1A1 mutations, however, it was di- rectly linked to the EEF1A1 allelic copy number loss and cell cycle-associated expression [18].

\section{Regulation of eEF1A by posttranslational modifications}

We switch now to the ways to control the eEF1A isoforms functionality in cells. Posttranslational modifications (PTM) represent a classical tactic to regulate the protein activity. There are several classes of PTM, including those acting on chromatin (methylation and acetylation), involved in signal transduction pathways (phosphorylation) and a number of other alterations of proteins. eEF1A belongs to the proteins subjected to different kinds of modifications including above mentioned phosphorylation, methylation and acetylation, as well as ubiquitination, sumoylation, succinylation, S-nitrozylation, glucosylation, S-gluthatylation, carbonylation etc. The location of the amino acid residues subjected to certain modifications in the structure of eEF1A is not always known, and the effect of the most of these modifications on the eEF1A activity is not clear so far. We will limit the review by relatively well described phosphorylation and methylation of eEF1A. The X-ray structure of eEF1A2, obtained by us recently $[31,32]$ is helpful for analysis of the effect of modifications in terms of spatial structure of the protein.

According to the PhosphositePlus database (https://www.phosphosite.org) the eEF1A1 molecule is more heavily modified than eEF1A2. The most frequently modified the phosphorylation sites in eEF1A1 and eEF1A2 are Tyr29 and Tyr141. Due to their intramolecular location, these sites were suggested to be mainly of structural importance [33]. 
However, after deciphering the eEF1A2 X-ray structure it was noticed that phosphorylation of Tyr29 can preclude the Tyr29-Trp58 interaction in eEF1A2 which, in turn, can influence stability of the A-A' helices linkage and result in an impairment of translation. Thus, the pool of eEF1A containing phosphoTyr29 may be directed to the non-translational processes in which eEF1A is involved [32].

The less frequent phosphorylation of Tyr85, Tyr86, Tyr162, Tyr254 and Tyr418 which are situated on the surface of the eEF1A molecule, is likely important for regulation of the interaction of eEF1A with some protein partners [33].

Phosphorylation of Ser21 in eEF1A could be important for the protein dimerization [34] while eEF1A dimers are suggested to be crucial for actin bundling [35]. Recently, the dimeric form of eEF1A has been proposed as an efficient target model for anti-cancer drugs directed towards inhibition of eEF1A [36] which suggests cytoskeleton-related mechanism of the phosphoSer21 involvement in C-Raf-induced apoptosis [34].

Methylation of Lys36, Lys55, Lys79 Lys165 and Lys318 has been found in mammalian eEF1A1 [37]. N-terminal $\alpha$-amine trimethylation has been also found [38]. Some of these residues were reported to be alternatively acetylated [39]. Possible regulatory importance of the methylation/acetylation and phosphorylation/acetylation switches has been recently discussed [40]. Methylation of Lys79 and Lys 318 is conserved in eukaryotes whereas methylation of Lys36 and Lys55 is conserved across most multicellular eukaryotes [37] which suggests a significance of such methylation. The methylation of each site is performed by a different methyltransferase [41].
The methylation could be a modulating rather than critically important factor for eEF1A, as none of these methyltransferases are essential in human cell lines [42].

It is worthy to note that ribosomal profiling data showed that the absence of Lys165 methylation in human cells resulted in multiple effects such as changes in ribosome biogenesis, chromatin, the endoplasmic reticulum and the unfolded protein response [43]. According to another ribosome profiling data set, the absence of Lys36 methylation may induce an increased translation of ribosomal proteins whereas the translation of the proteins associated with tRNA aminoacylation (aminoacyltRNA synthetases and related proteins) can be decreased [44]. The translation of proteins representing endoplasmic reticulum was also reduced. Moreover, the lack of methylation of Lys36 influenced the translation rates for some codons. Importantly, a similar effect was observed upon the absence of Lys55 methylation [38].

Possible mechanisms responsible for a link between Lys 36, Lys55 and Lys 165 methylation in eEF1A1 and multiple ribosomal effects remains to be studied. The X-ray structure of eEF1A2*GDP $[31,32]$ and cryoEM structures of eEF1A1 at different elongation steps on the $80 \mathrm{~S}$ ribosome [45] show that the methylated residues of eEF1A are situated rather far from the ribosome in the eEF1A-ribosome complex and apparently not involved into the interaction with the translational partners of eEF1A. Therefore, it appears difficult to realize why the translation of one protein is influenced and the other is not. Additional problem of the understanding of this effect is related to the apparently dynamic character of the methyla- 
tion of eEF1A which was reported at least in the case of Lys 165 methylation in HeLa cells [43] representing a mixture of non-methylated, mono-, di- and tri-methylated residues. However, the dynamic methylation is not a rule as, for instance, trimethylated Lys-36 species was found to be predominant in various mammalian cells and tissues [44].

Elucidation of a functional effect of the eEF1A modifications becomes even more complicated if one would take into account a possibility of "cross-talk" between different modification types. For instance, phosphorylated Ser163 is situated near Lys165 which is dimethylated in the A1 isoform and trimethylated in the A2 isoform. In this case, cross-talk between the modifications can form an exclusive isoform-specific local landscape, which can contribute to the differential distribution and/ or functions of eEF1A1 and eEF1A2 via interaction with different protein partners [32].

\section{Regulation of eEF1A by macromolecular partners}

It is becoming increasingly clear that the protein-protein interaction network provides a significant contribution to the cell regulation processes. Alterations in these interactions can introduce a disorder in the interconnected protein networks causing serious consequences for a cell. Until recently, main attention of the researchers was concentrated on deciphering and description of the signaling cross-talks, however, the recent reviews have shown good examples of regulatory importance of the protein-protein interactions as well [46-48].

For instance, histone methyl-transferase PRDM14 was shown to bind to transcription factor HOXA1 and negatively influenced its stability and activity [49]. The direct interaction of transcription factor phosphate starvation response 1 (PHR1) with its downstream target SPX1 was shown to regulate the PSI gene expression by tuning the PHR1-DNAbinding equilibrium [50].

In Trypanosoma cruzi, the enolase ENO activity was inhibited by direct binding of metallocarboxypeptidase- 1 and acireductone dioxygenase [51].

The role of protein-protein interactions in modulating synaptic plasticity in the hippocampus has been approached quite recently. The 14-3-3 family of proteins participates in the hippocampal long term potentiation process (LTP). Protein RGS14 is implicated in suppression of LTP in the CA2 region of the hippocampus, thereby regulating hippocampalbased learning and memory. These proteins were shown to directly interact in cells, and one of the two distinct interaction sties was shown to be phosphorylation independent while the other was phosphorylation-dependent, contributing to negative regulation of RGS14 functions [52].

Peroxisome proliferator-activated receptor (PPAR) $\delta$ which is an established therapeutic target in different disorders, in ligand-activated form can directly interact with the protooncogene product c-Myc. The interaction of PPAR $\delta$ with c-Myc was shown to suppress the transcriptional activity of c-Myc and the expression of its target genes. Moreover, the $\operatorname{PPAR} \delta$-dependent inhibition of c-Myc activity was associated with decreased tumorigenicity in breast cancer cells [53].

An interesting example of isoform-specific difference has been given recently for the two isoforms of the main regulatory subunits of 
Class IA phosphatidylinositol 3-kinase (PI3K), $\mathrm{p} 85 \alpha$ and $\mathrm{p} 85 \beta$. These isoforms initiated different cellular activities due to their interaction with different regulatory proteins and independently of their binding to the catalytic subunit p110 [54].

Thus, the important aspect for clarifying how the isoform-specific functions of eEF1A 1 and eEF1A2 are controlled in mammalian cells is the understanding of whether these isoforms are able to bind different protein targets, or the same target but with different affinity.

The strong background for the potential interaction dissimilarity is provided by our data on significant difference in spatial structures of the isoform proteins. eEF1A1 was shown to have an open structure while eEF1A2 possesses closed, compact form [55, 56]. Also, different accessibility to Tyr phosphorylation hinted on the possible variation in local spatial organization of the isoforms [57]. Multiple molecular dynamic simulations indicated specific molecular regions which could be different in the two isoforms and consequently contribute to the different ability to interact with protein partners [58].

Indeed, a different spatial organization of the eEF1A1 and eEF1A2 proteins was shown to correlate with their different ability to interact with a number of partners. Most importantly, a possibility of a regulatory effect of such difference was demonstrated. For instance, eEF1A1 was able to form a strong complex with calmodulin in the presence of $\mathrm{Ca}^{2+}$ whereas eEF1A2 was not [59]. This phenomenon becomes even more interesting in light of the ability of calmodulin to compete with tRNA for eEF1A1 [59]. Importantly, one more player in the elongation cycle, translation elongation factor $1 \mathrm{~B} \alpha$, responsible for nucleotide exchange in eEF1A, interacts with the same area of eEF1A [60]. Thus, a multiple regulatory effect of calmodulin on translation is possible. The inability of eEF1A2 to interact with calmodulin suggests a lack of such regulation in excitable tissues where eEF1A2 is exclusively expressed. This might evidence some mechanism of protection of the protein synthesis process from the sharp and permanently occurring changes in $\mathrm{Ca}^{2+}$ concentrations in some specialized eEF1A2-specific cells.

A well-known cellular partner of eEF1A in eukaryotic cells is actin. The eEF1A1-actin interaction was demonstrated long time ago [61] while the information about the actineEF1A2 interaction was absent until recently when the different shape of F-actin bundles formed in the presence of eEF1A1 or eEF1A2 was discovered [59]. As actin cytoskeleton shows significant perturbations in cancer cells [62], the oncogene eEF1A2 may contribute to these changes.

We have shown that eEF1A1-mediated bundling of F-actin decreases significantly in the presence of $\mathrm{Ca}^{2+}$-calmodulin [59]. Thus, the interaction of eEF1A1 with F-actin may be controlled by calmodulin in $\mathrm{Ca}^{2+}$-dependent manner whereas there is no calmodulin-dependence of the eEF1A2-F-actin interaction. It means that, upon a high level expression of eEF1A2 in a normally non-specific for eEF1A2 tissue, newly appeared eEF1A2 may stay beyond conventional for eEF1A1 regulation in this tissue. This can permit eEF1A2 to take part in the cellular processes different from those involving eEF1A1, including oncogenic transformation. 
Protein Sgt1 is a multifunctional protein, one of its roles is to contribute to the anti-viral protection of an organism via "non-host" resistance [63], this permits to suggest that Sgt1 could be an important factor limiting the viral multiplication via unknown yet mechanism [64]. As there are several reports on the positive involvement of eEF1A in viral pathogenesis as well [65-67], a possibility of the interaction of the two proteins was checked and confirmed [68]. It was shown that the eEF1A1 isoform readily forms a complex with Sgt1 while eEF1A2 does not.

eEF1A1 can interact with viral RNA and/ or RNA polymerase [69]. As one of the Sgt1 domains is highly negatively charged it can mimic the negatively charged surface of RNA. Molecular docking experiments showed that this domain can be involved into the interaction with eEF1A1. Therefore, it appeared likely that antiviral protein Sgt1 can compete with viral RNA for eEF1A1. This possibility was tested in the direct in vitro experiments showing that Sgt1 can force RNA of tobacco mosaic virus out of eEF1A1 [68]. Also, the excess of this RNA negatively influenced formation of the eEF1A1-Sgt1 complex. These data suggest a possibility of the novel mechanism of the antiviral Sgt1 action relying on the competition of Sgt1 with viral RNA for proviral eEF1A1.

Interestingly, eEF1A2 shows an increased affinity to viral RNA [68] and, at the same time, this interaction cannot be influenced by $\mathrm{Ca}^{2+}$ calmodulin [59]. This suggests a possibility of the strong pro-viral action of eEF1A2 which could be a subject of further investigations.

Thus, the protein-protein or the proteinRNA interplay can be an important factor which controls eEF1A functioning in the translational and non-translational processes in the eukaryotic cell.

\section{4. eEF1A*GDP*aminoacyl-tRNA-me- diated regulation of $\mathrm{mRNA}$ translation}

In eukaryotic cells, the movement of the ribosomes along mRNA is controlled mainly by the various strength of the different codonanticodon interactions and the effects of the secondary structure of mRNA [70]. The elongation factors are involved as well, but the main target for regulation is believed to be the elongation factor eEF2 [71] whereas eEF1A does not attract much attention as a regulatory agent for translation. Recently we have published a hypothesis describing a possible significance of the nature of eEF1A*GDP*aminoacyl-tRNA complexes present in the A site of $80 \mathrm{~S}$ ribosomes for the ribosomal elongation rate. It is based on our previous estimations of different stability of the eEF1A*GDP complexes with different tRNA [72, 73, 74] and recent cryoEM data showing that a substantial amount of eEF1A*GDP is bound to aminoacyl-tRNA in the mammalian 80S ribosome [45]. We hypothesized that the unexpected presence of the eEF1A*GDP*aminoacyl-tRNA complex in the mammalian ribosomes suggests a critical importance of the eEF1A*GDP dissociation step for the proceeding of the elongation step of translation in Mammalia. That is quite opposite to what is known about the prokaryotic elongation where aminoacyl-tRNA dissociates from EF-Tu*GDP immediately after GTP hydrolysis [75]. Importantly, the translation elongation rate of the prokaryotic ribosomes normally exceeds that of the eukaryotic ones $[76,77]$. Thus, slow dissociation of 
eEF1A $1 *$ GDP from aminoacyl-tRNA residing on the $80 \mathrm{~S}$ ribosome can be the rate-limiting step of translation elongation. Importantly, the affinity of eEF1A*GDP for tRNA of different specificities is not equal, i.e. dissociation constants of different complexes were calculated to vary in a range of one order of magnitude [78]. One cannot exclude that the kinetic parameters of dissociation of the different eEF1A*GDP*aminoacyl-tRNA complexes are diverse as well. If the dissociation rates of the eEF1A*GDP complexes with various aminoacyl-tRNAs situated in the ribosomal A site are different, this may influence the ribosomal elongation rate in general, depending on the tRNA nature. Consequently, this provides a novel mechanism explaining how the rate of mRNA translation can depend on amino acids, coded by this mRNA. Here, eEF1A*GDP and tRNA play a role of signal transmitters. In such a way eEF1A may control the elongation rate independently from the codon-anticodon correspondence and the mRNA secondary structure.

Importantly, apart from the general elongation control, this mechanism can be responsible for different efficiency of ribosomal elongation of nascent polypeptides in the presence of the eEF1A1 or eEF1A2 isoforms. It is known that the complexes of eEF1A2*GDP with tRNA are essentially more stable that analogous complexes of eEF1A1*GDP [74]. If out hypothesis is correct, a less efficient translation elongation should be observed in the presence of eEF1A2 rather than eEF1A1. A suitable model to check a validity of the assumption is glial and neuronal cells of the brain. It is known that eEF1A1 is exclusively present in glial cells while eEF1A2 is the only
eEF1A isoform found in neurons [79]. Indeed, the literature data on ribosomal transit time in both kinds of cells showed that in the presence of eEF1A2 the elongation rate is nearly 7 times slower than in the presence of eEF1A1 [80, 81]. A slower elongation rate in such highly specialized cells as neurons, myocytes and cardiomyocytes where the only expression of eEF1A2 is observed, is probably useful to decrease translation errors as the rate of elongation may be inversely proportional to the elongation fidelity $[82,83]$. In the cancer cells demonstrating decreased translation fidelity [84] the appearance of oncogenic eEF1A2 may contribute to smoothing out this apparently negative effect.

Consequently, eEF1A*GDP can contribute to the translation efficiency at the level of its dissociation from the $80 \mathrm{~S}$ ribosome depending on the nature of aminoacyl-tRNA bound. Moreover, as eEF1A2 shows an increased as compared to eEF1A1 strength of the eEF1A*GDP*tRNA complexes, the efficiency of polypeptide elongation on certain mRNAs in the presence of eEF1A2 could be less than in the presence of eEF1A1. These predictions show a novel possibility of the eEF1A*GDPmediated regulation of the ribosomal elongation rate.

\section{Concluding remarks}

This review describes several ways to control the eEF1A isoforms in mammalian cells (Fig. 1). They could affect both the amount and functionality of the eEF1A proteins in vivo.

The amount of the eEF1A1 and eEF1A2 proteins in the cell is regulated at the level of their synthesis rather than degradation. Namely, 
the level of eEF1A1 mRNA in tumors is downregulated, in particular, due to the EEF1A1 allelic copy number loss while the overexpression of eEF1A2 mRNA occurs mainly due to the micro-RNA mediated regulation.

The functionality of the eEF1A1 and eEF1A2 proteins can be regulated by several ways including different post-translational modifications and distinct abilities of the isoforms to interact with different RNA and protein partners. eEF1A1 shows the increased ability to interact with various protein partners and is more subjected to the post-translational modifications, as compared to eEF1A2. However, eEF1A2 demonstrates a stronger than eEF1A1 ability to form the complexes with different RNAs, including tRNA of various amino acid specificities and viral RNA.

It was assumed that the eEF1A2 protein may be less important (compared to eEF1A1) at least for $\mathrm{Ca}^{2+}$-modulated cellular control [59]. In such way the translation process in muscle, myocardial and neuronal tissues could resist to permanent changes in $\mathrm{Ca}^{2+}$ concentrations occurring in these tissues. In the case the proto-oncogenic eEF1A2 expression is initi- ated in the tissues where the exclusive functioning of eEF1A1 is normally observed, the eEF1A2 isoform cannot be regulated in eEF1A1-specufic manner, thus acting beyond control and acquiring oncogenic properties [59].

eEF1A1 is a known pro-viral agent which can bind viral RNA and RNA-polymerase and accelerate virus replication [15]. Consequently, another disease-related capacity of eEF1A2 may be coupled to the increased, as compared to eEF1A1, RNA-binding ability of the former. Because of this, a role of eEF1A2 in viral replication could be even more pronounced than that of eEF1A1. One cannot exclude that oncogenic eEF1A2 may significantly contribute to elevated expression of viral genomic RNA, infectious virus proliferation and the release of cancer-related RNA-containing viruses, such as viruses of hepatitis B and hepatitis C $[85,86]$, Moloney murine leukemia virus-1 [87] etc.

Thus, despite a very high sequence homology and similar translation involvement in different tissues, the eEF1A1 and eEF1A2 isoforms are very different in both terms of

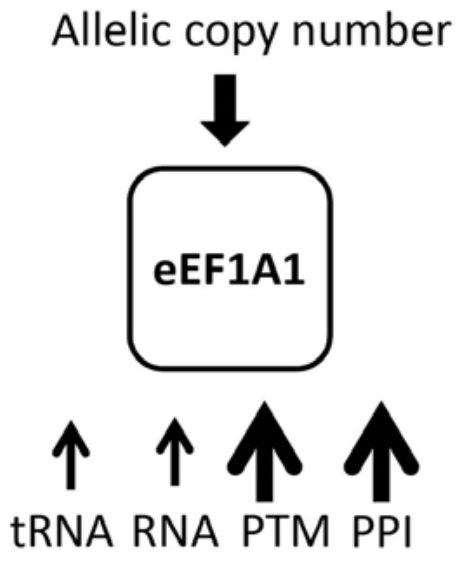

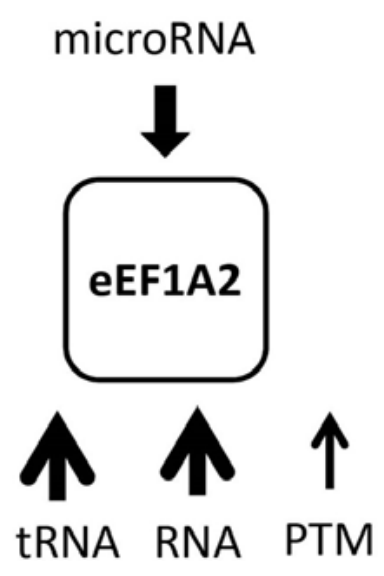

Fig. 1. Regulation of the eEF1A1 and eEF1A2 isoforms. PTM - posttranslational modifications, PPI protein-protein interactions. Bold arrows indicate stronger effect while plain arrows indicate milder effect of the same effector on one isoform as compared to another isoform. 
spatial organization of their macromolecules and regulation of their activity. The described regulatory mechanisms specific for each isoform are mostly based on the in vitro studies and now await further analysis at the level of organism.

\section{Acknowledgements}

We are grateful to Prof. Anna El'skaya for continuous support of the studies of the Laboratory of Protein Biosynthesis that were partly described in this review. The financial support from the Programs of National Academy of Sciences of Ukraine "Molecular and Cellular Technologies for Medicine, Industry and Agriculture" and "Moleculargenetic and biochemical mechanisms of the regulation of cellular and system interactions at physiological and pathological states" is appreciated.

\section{REFERENCES}

1. El'skaya AV, Negrutskii BS, Shalak V, Vislovukh A, Vlasenko D, Novosylna A, Lukash T, Veremieva $M$. Specific features of protein biosynthesis in higher eukaryotes. Biopolym Cell. 2013; 29(3): 177-87.

2. Abbott CM, Newbery HJ, Squires CE, Brownstein D, Griffiths LA, Soares DC. eEF1A2 and neuronal degeneration. Biochem Soc Trans. 2009;37(Pt 6): 1293-7.

3. Novosylna $O$. Protein isoforms. Origin, structure and functions. Biopolym Cell. 2017; 33(3): 161-71.

4. Mishra AK, Gangwani L, Davis RJ, Lambright DG. Structural insights into the interaction of the evolutionarily conserved ZPR1 domain tandem with eukaryotic EF1A, receptors, and SMN complexes. Proc Natl Acad Sci U S A. 2007;104(35):13930-5.

5. Bandyopadhyay U, Sridhar S, Kaushik S, Kiffin R, Cuervo AM. Identification of regulators of chaperone-mediated autophagy. Mol Cell. 2010;39(4): 535-47.
6. Chang $R$, Wang E. Mouse translation elongation factor eEF1A-2 interacts with Prdx-I to protect cells against apoptotic death induced by oxidative stress. $J$ Cell Biochem. 2007;100(2):267-78.

7. Borradaile NM, Buhman KK, Listenberger LL, Magee CJ, Morimoto ET, Ory DS, Schaffer JE. A critical role for eukaryotic elongation factor 1A-1 in lipotoxic cell death. Mol Biol Cell. 2006;17(2):770-8.

8. Lukash TO, Turkivska HV, Negrutskii BS, El'skaya $A V$. Chaperone-like activity of mammalian elongation factor eEF1A: renaturation of aminoacyl-tRNA synthetases. Int $J$ Biochem Cell Biol. 2004;36(7):1341-7.

9. Ransom-Hodgkins WD, Brglez I, Wang X, Boss WF. Calcium-regulated proteolysis of eEF1A. Plant Physiol. 2000;122(3):957-65.

10. Tarrant DJ, Stirpe M, Rowe M, Howard MJ, von der Haar T, Gourlay $C W$. Inappropriate expression of the translation elongation factor 1A disrupts genome stability and metabolism. $J$ Cell Sci. 2016;129(24):4455-4465.

11. Tash JS, Attardi B, Hild SA, Chakrasali R, Jakkaraj SR, Georg GI. A novel potent indazole carboxylic acid derivative blocks spermatogenesis and is contraceptive in rats after a single oral dose. Biol Reprod. 2008;78(6):1127-38.

12. Jeganathan S, Morrow A, Amiri A, Lee JM. Eukaryotic elongation factor $1 \mathrm{~A} 2$ cooperates with phosphatidylinositol-4 kinase III beta to stimulate production of filopodia through increased phosphatidylinositol-4,5 bisphosphate generation. Mol Cell Biol. 2008;28(14):4549-61.

13. Goulart-Silva F, Serrano-Nascimento C, Nunes MT. Hypothyroidism decreases proinsulin gene expression and the attachment of its mRNA and eEF1A protein to the actin cytoskeleton of INS-1E cells. Braz J Med Biol Res. 2011;44(10):1060-7.

14. Gross SR, Kinzy TG. Translation elongation factor $1 \mathrm{~A}$ is essential for regulation of the actin cytoskeleton and cell morphology. Nat Struct Mol Biol. 2005;12(9):772-8.

15. Abbas W, Kumar A, Herbein $G$. The eEF1A Proteins: At the Crossroads of Oncogenesis, Apoptosis, and Viral Infections. Front Oncol. 2015;5:75. eCollection 2015. 
16. Tomlinson VA, Newbery HJ, Wray NR, Jackson J, Larionov A, Miller WR, Dixon JM, Abbott CM. Translation elongation factor eEF1A2 is a potential oncoprotein that is overexpressed in two-thirds of breast tumours. BMC Cancer. 2005;5:113.

17. Anand N, Murthy S, Amann G, Wernick M, Porter LA, Cukier IH, Collins C, Gray JW, Diebold J, Demetrick DJ, Lee JM. Protein elongation factor EEF1A2 is a putative oncogene in ovarian cancer. Nat Genet. 2002;31(3):301-5.

18. Lin CY, Beattie A, Baradaran B, Dray E, Duijf PHG. Contradictory mRNA and protein misexpression of EEF1A1 in ductal breast carcinoma due to cell cycle regulation and cellular stress. Sci Rep. 2018;8(1):13904.

19. Hassan MK, Kumar D, Naik M, Dixit M. The expression profile and prognostic significance of eukaryotic translation elongation factors in different cancers. PLoS One. 2018;13(1):e0191377.

20. Vislovukh AA, Gralievska NL, Naumovets $M G, N e-$ grutskii BS, El'skaya AV. mRNAs coding for A1 and A2 isoforms of translation factor eEF1A demonstrate different half-lives while A1 and A2 proteins are similarly stable in MCF7 cells. Biopolym Cell. 2013; 29(5): 389-94.

21. Vislovukh AA, Naumovets $M G$, Kovalenko MI, Groisman RS, Groisman IS, Negrutskii BS, El'skaya $A V$. Isoforms of elongation factor eEF1A may be differently regulated at post-transcriptional level in breast cancer progression. Biopolym Cell. 2013; 29(1): 55-63.

22. Vislovukh A, Groisman I, El'skaya A, Negrutskii B, Polesskaya A. Transcriptional and post-transcriptional control of eEF1A2 expression during myoblast diffrerentiation. Biopolym Cell. 2012; 28(6): 456-60.

23. Vislovukh A, Kratassiouk G, Porto E, Gralievska N, Beldiman C, Pinna G, El'skaya A, Harel-Bellan A, Negrutskii B, Groisman I. Proto-oncogenic isoform A2 of eukaryotic translation elongation factor eEF1 is a target of miR-663 and miR-744. Br J Cancer. 2013;108(11):2304-11.

24. Zang $W$, Wang $Y$, Wang $T$, Du $Y$, Chen $X$, Li $M$, Zhao G. miR-663 attenuates tumor growth and invasiveness by targeting eEF1A2 in pancreatic cancer. Mol Cancer. 2015;14:37.
25. Chen $Q$, Zhao T, Xie X, Yu D, Wu L, Yu W, Sun $W$. MicroRNA-663 regulates the proliferation of fibroblasts in hypertrophic scars via transforming growth factor- $\beta 1$. Exp Ther Med. 2018;16(2):1311-1317.

26. Fiori ME, Villanova L, Barbini C, De Angelis $M L$, De Maria R. miR-663 sustains NSCLC by inhibiting mitochondrial outer membrane permeabilization (MOMP) through PUMA/BBC3 and BTG2. Cell Death Dis. 2018;9(2):49.

27. Liang S, Zhang N, Deng Y, Chen L, Zhang Y, Zheng Z, Luo W, Lv Z, Li S, Xu T. miR-663 promotes NPC cell proliferation by directly targeting CDKN2A. Mol Med Rep. 2017;16(4):4863-4870.

28. Kleemann M, Schneider H, Unger K, Sander P, Schneider EM, Fischer-Posovszky P, Handrick R, Otte $K$. MiR-744-5p inducing cell death by directly targeting HNRNPC and NFIX in ovarian cancer cells. Sci Rep. 2018;8(1):9020.

29. Shen J, Li M. MicroRNA-744 inhibits cellular proliferation and invasion of colorectal cancer by directly targeting oncogene Notch1. Oncol Res. 2018.

30. Li JZ, Gao W, Lei WB, Zhao J, Chan JY, Wei WI, Ho WK, Wong TS. MicroRNA 744-3p promotes MMP-9-mediated metastasis by simultaneously suppressing PDCD4 and PTEN in laryngeal squamous cell carcinoma. Oncotarget. 2016;7(36):58218-58233.

31. Yaremchuk A, Shalak VF, Novosylna OV, Negrutskii BS, Crépin T, El'skaya AV, Tukalo M. Purification, crystallization and preliminary X-ray crystallographic analysis of mammalian translation elongation factor eEF1A2. Acta Crystallogr Sect F Struct Biol Cryst Commun. 2012;68(Pt 3):295-7.

32. Crepin T, Shalak VF, Yaremchuk AD, Vlasenko DO, McCarthy A, Negrutskii BS, Tukalo MA, El'skaya AV. Mammalian translation elongation factor eEF1A2: X-ray structure and new features of GDP/GTP exchange mechanism in higher eukaryotes. Nucleic Acids Res. 2014;42(20):12939-48.

33. Negrutskii B, Vlasenko D, El'skaya A. From global phosphoproteomics to individual proteins: the case of translation elongation factor eEF1A. Expert Rev Proteomics. 2012;9(1):71-83.

34. Sanges C, Scheuermann C, Zahedi RP, Sickmann A, Lamberti A, Migliaccio N, Baljuls A, Marra M, Zappavigna S, Reinders J, Rapp U, Abbruzzese A, 
Caraglia M, Arcari P. Raf kinases mediate the phosphorylation of eukaryotic translation elongation factor $1 \mathrm{~A}$ and regulate its stability in eukaryotic cells. Cell Death Dis. 2012;3:e276. Erratum in: Cell Death Dis. 2012;3:e317.

35. Vlasenko DO, Novosylna OV, Negrutskii BS, El'skaya $A V$. Truncation of the A,A(*), A' helices segment impairs the actin bundling activity of mammalian eEF1A1. FEBS Lett. 2015;589(11):1187-93. doi: 10.1016/j.febslet.2015.03.030.

36. Sánchez-Murcia PA, Cortés-Cabrera Á, Gago F. Structural rationale for the cross-resistance of tumor cells bearing the A399V variant of elongation factor eEF1A1 to the structurally unrelated didemnin B, ternatin, nannocystin A and ansatrienin B. J Comput Aided Mol Des. 2017;31(10):915-928.

37. Hamey JJ, Wilkins MR. Methylation of Elongation Factor 1A: Where, Who, and Why? Trends Biochem Sci. 2018;43(3):211-223.

38. Jakobsson ME, Małecki JM, Halabelian L, Nilges BS, Pinto R, Kudithipudi S, Munk S, Davydova E, Zuhairi FR, Arrowsmith $\mathrm{CH}$, Jeltsch A, Leidel SA, Olsen JV, Falnes PØ. The dual methyltransferase METTL13 targets N terminus and Lys55 of eEF1A and modulates codon-specific translation rates. Nat Commun. 2018;9(1):3411.

39. Zhao $S$, Xu W, Jiang $W$, Yu W, Lin Y, Zhang T, Yao J, Zhou L, Zeng Y, Li H, Li Y, Shi J, An W, Hancock SM, He F, Qin L, Chin J, Yang P, Chen X, Lei $Q$, Xiong Y, Guan KL. Regulation of cellular metabolism by protein lysine acetylation. Science. 2010;327(5968):1000-4.

40. Grimes M, Hall B, Foltz L, Levy T, Rikova K, Gaiser J, Cook W, Smirnova E, Wheeler T, Clark NR, Lachmann A, Zhang B, Hornbeck P, Ma'ayan A, Comb $M$. Integration of protein phosphorylation, acetylation, and methylation data sets to outline lung cancer signaling networks. Sci Signal. 2018;11(531). pii: eaaq1087.

41. Jakobsson ME, Małecki J, Falnes PØ. Regulation of eukaryotic elongation factor 1 alpha (eEF1A) by dynamic lysine methylation. RNA Biol. 2018;15(3): 314-319.

42. Wang T, Birsoy K, Hughes NW, Krupczak KM, Post Y, Wei JJ, Lander ES, Sabatini DM. Identifica- tion and characterization of essential genes in the human genome. Science. 2015;350(6264):1096-101. 43. Malecki J, Aileni VK, Ho AYY, Schwarz J, Moen A, Sørensen V, Nilges BS, Jakobsson ME, Leidel SA, Falnes $P \emptyset$. The novel lysine specific methyltransferase METTL21B affects mRNA translation through inducible and dynamic methylation of Lys165 in human eukaryotic elongation factor 1 alpha (eEF1A). Nucleic Acids Res. 2017;45(8):4370-4389. 44. Jakobsson ME, Malecki J, Nilges BS, Moen A, Leidel SA, Falnes PØ. Methylation of human eukaryotic elongation factor alpha (eEF1A) by a member of a novel protein lysine methyltransferase family modulates mRNA translation. Nucleic Acids Res. 2017;45(14):8239-8254.

45. Behrmann E, Loerke J, Budkevich TV, Yamamoto K, Schmidt A, Penczek PA, Vos MR, Bürger J, Mielke T, Scheerer P, Spahn CM. Structural snapshots of actively translating human ribosomes. Cell. 2015;161(4):845-57.

46. De Melo J, He L, Tang D. The protein-protein interaction-mediated inactivation of PTEN. Curr Mol Med. 2014;14(1):22-33.

47. Oladimeji P, Cui H, Zhang C, Chen T. Regulation of PXR and CAR by protein-protein interaction and signaling crosstalk. Expert Opin Drug Metab Toxicol. 2016;12(9):997-1010.

48. Jubb HC, Pandurangan AP, Turner MA, OchoaMontaño B, Blundell TL, Ascher DB. Mutations at protein-protein interfaces: Small changes over big surfaces have large impacts on human health. Prog Biophys Mol Biol. 2017;128:3-13.

49. Draime A, Bridoux L, Belpaire M, Pringels T, Tys $J$, Rezsohazy R. PRDM14, a putative histone methyltransferase, interacts with and decreases the stability and activity of the HOXA1 transcription factor. Biochim Biophys Acta Gene Regul Mech. 2018; 1861(5):534-542.

50. Qi W, Manfield IW, Muench SP, Baker A. AtSPX1 affects the AtPHR1-DNA-binding equilibrium by binding monomeric AtPHR1 in solution. Biochem $J$. 2017;474(21):3675-3687.

51. Quintero-Troconis E, Buelvas N, Carrasco-López C, Domingo-Sananes MR, González-González L, Ramírez-Molina $R$, Osorio L, Lobo-Rojas A, 
Cáceres AJ, Michels PA, Acosta H, Quiñones W, Concepción JL. Enolase from Trypanosoma cruzi is inhibited by its interaction with metallocarboxypeptidase-1 and a putative acireductone dioxygenase. Biochim Biophys Acta Proteins Proteom. 2018;1866(5-6):651-660.

52. Gerber KJ, Squires KE, Hepler JR. 14-3-3 $\gamma$ binds regulator of $\mathrm{G}$ protein signaling 14 (RGS14) at distinct sites to inhibit the RGS14:Ga(i)-AlF(4)(-) signaling complex and RGS14 nuclear localization. J Biol Chem. 2018;293(38):14616-14631.

53. Ham SA, Kim E, Yoo T, Lee WJ, Youn JH, Choi MJ, Han SG, Lee CH, Paek KS, Hwang JS, Seo HG. Ligand-activated interaction of PPAR $\delta$ with c-Myc governs the tumorigenicity of breast cancer. Int $J$ Cancer. 2018;143(11):2985-2996. .

54. Ito $Y$, Hart JR, Vogt PK. Isoform-specific activities of the regulatory subunits of phosphatidylinositol 3-kinases - potentially novel therapeutic targets. Expert Opin Ther Targets. 2018;22(10):869-877.

55. Novosylna A, Timchenko A, Tiktopulo E, Serdyuk I, Negrutskii B, El Skaya A. Characterization of physical properties of two isoforms of translation elongation factor 1A. Biopolym Cell. 2007; 23(5): 386-90.

56. Timchenko AA, Novosylna OV, Prituzhalov EA, Kihara H, El'skaya AV, Negrutskii BS, Serdyuk IN. Different oligomeric properties and stability of highly homologous A1 and proto-oncogenic A2 variants of mammalian translation elongation factor eEF1. Biochemistry. 2013;52(32):5345-53.

57. Panasyuk G, Nemazanyy I, Filonenko V, Negrutskii B, El'skaya $A V$. A2 isoform of mammalian translation factor eEF1A displays increased tyrosine phosphorylation and ability to interact with different signalling molecules. Int $J$ Biochem Cell Biol. 2008;40(1):63-71.

58. Kanibolotsky DS, Novosyl'na OV, Abbott CM, Negrutskii BS, El'skaya AV. Multiple molecular dynamics simulation of the isoforms of human translation elongation factor $1 \mathrm{~A}$ reveals reversible fluctuations between «open» and «closed» conformations and suggests specific for eEF1A1 affinity for $\mathrm{Ca} 2+$-calmodulin. BMC Struct Biol. 2008;8:4.
59. Novosylna O, Doyle A, Vlasenko D, Murphy M, Negrutskii B, El'skaya A. Comparison of the ability of mammalian eEF1A1 and its oncogenic variant eEF1A2 to interact with actin and calmodulin. Biol Chem. 2017;398(1):113-124. doi: 10.1515/hsz2016-0172.

60. Andersen GR, Pedersen L, Valente L, Chatterjee I, Kinzy TG, Kjeldgaard M, Nyborg J. Structural basis for nucleotide exchange and competition with tRNA in the yeast elongation factor complex eEF1A: eEF1Balpha. Mol Cell. 2000;6(5):1261-6.

61. Edmonds BT, Wyckoff J, Yeung YG, Wang Y, Stanley ER, Jones J, Segall J, Condeelis J. Elongation factor-1 alpha is an overexpressed actin binding protein in metastatic rat mammary adenocarcinoma. J Cell Sci. 1996;109 (Pt 11): 2705-14.

62. Stevenson RP, Veltman D, Machesky LM. Actinbundling proteins in cancer progression at a glance. J Cell Sci. 2012;125(Pt 5):1073-9.

63. Peart JR, Lu R, Sadanandom A, Malcuit I, Moffett P, Brice DC, Schauser L, Jaggard DA, Xiao S, Coleman MJ, Dow M, Jones JD, Shirasu K, Baulcombe $D C$. Ubiquitin ligase-associated protein SGT1 is required for host and nonhost disease resistance in plants. Proc Natl Acad Sci US A. 2002;99(16):10865-9.

64. Komatsu K, Hashimoto M, Ozeki J, Yamaji Y, Maejima K, Senshu H, Himeno M, Okano Y, Kagiwada $S$, Namba $S$. Viral-induced systemic necrosis in plants involves both programmed cell death and the inhibition of viral multiplication, which are regulated by independent pathways. Mol Plant Microbe Interact. 2010;23(3):283-93.

65. Li D, Wei T, Rawle DJ, Qin F, Wang R, Soares DC, Jin H, Sivakumaran H, Lin MH, Spann K, Abbott $C M$, Harrich D. Specific Interaction between eEF1A and HIV RT Is Critical for HIV-1 Reverse Transcription and a Potential Anti-HIV Target. PLoS Pathog. 2015;11(12):e1005289.

66. Luan H, Shine MB, Cui X, Chen X, Ma N, Kachroo P, Zhi H, Kachroo A. The Potyviral P3 Protein Targets Eukaryotic Elongation Factor 1A to Promote the Unfolded Protein Response and Viral Pathogenesis. Plant Physiol. 2016;172(1):221-34. 
67. Rawle DJ, Li D, Swedberg JE, Wang L, Soares DC, Harrich D. HIV-1 Uncoating and Reverse Transcription Require eEF1A Binding to Surface-Exposed Acidic Residues of the Reverse Transcriptase Thumb Domain. MBio. 2018;9(2). pii: e00316-18.

68. Novosylna O, Jurewicz E, Pydiura N, Goral A, Filipek A, Negrutskii B, El'skaya A. Translation elongation factor eEF1A1 is a novel partner of a multifunctional protein Sgt1. Biochimie. 2015;119:137-45.

69. Li D, Wei T, Abbott CM, Harrich D. The unexpected roles of eukaryotic translation elongation factors in RNA virus replication and pathogenesis. Microbiol Mol Biol Rev. 2013;77(2):253-66.

70. Pop C, Rouskin S, Ingolia NT, Han L, Phizicky EM, Weissman JS, Koller D. Causal signals between codon bias, mRNA structure, and the efficiency of translation and elongation. Mol Syst Biol. 2014;10:770.

71. Tsuda-Sakurai K, Miura M. The Hidden Nature of Protein Translational Control by Diphthamide - the secrets under the leather. $J$ Biochem. 2019;165(1):1-8.

72. Futernyk P, Pogribna A, Petrushenko Z, Negrutski B, El'skaya $G$. Investigation of the complexes of elongation factor 1A with tRNASer and seryl-tRNA synthetase. Biopolym Cell. 2004; 20(1-2): 17-23.

73. Futernyk P, Negrutskii B, El'ska G. Noncanonical complexes of mammalian eEF1A with various deacylated tRNAs. Biopolym Cell. 2008; 24(6): 453-62.

74. Futernyk P, Negrutskii B, El'skaya A. Interaction of different tRNAs with translation elongation factors 1A from lower and higher eukaryotes. Biopolym Cell. 2009; 25(6): 457-65.

75. Pape T, Wintermeyer $W$, Rodnina MV. Complete kinetic mechanism of elongation factor Tu-dependent binding of aminoacyl-tRNA to the A site of the E. coli ribosome. EMBO J. 1998;17(24):7490-7.

76. Bonven B, Gulløv K. Peptide chain elongation rate and ribosomal activity in Saccharomyces cerevisiae as a function of the growth rate. Mol Gen Genet. 1979;170(2):225-30.

77. Bouadloun F, Donner D, Kurland CG. Codon-specific missense errors in vivo. EMBO J. 1983;2(8):1351-6.

78. Negrutskii B, Vlasenko D, Mirande M, Futernyk $P$, El'skaya $A$. mRNA-Independent way to regulate translation elongation rate in eukaryotic cells. IUBMB Life. 2018;70(3):192-196.
79. Newbery HJ, Loh DH, O'Donoghue JE, Tomlinson VA, Chau YY, Boyd JA, Bergmann JH, Brownstein $D$, Abbott $C M$. Translation elongation factor eEF1A2 is essential for post-weaning survival in mice. J Biol Chem. 2007;282(39):28951-9.

80. Takei N, Kawamura M, Ishizuka Y, Kakiya N, Inamura $N$, Namba H, Nawa H. Brain-derived neurotrophic factor enhances the basal rate of protein synthesis by increasing active eukaryotic elongation factor 2 levels and promoting translation elongation in cortical neurons. $\mathrm{J}$ Biol Chem. 2009;284(39):26340-8.

81. Barrera I, Flores-Méndez M, Hernández-Kelly LC, Cid L, Huerta M, Zinker S, López-Bayghen E, Aguilera J, Ortega A. Glutamate regulates eEF1A phosphorylation and ribosomal transit time in Bergmann glial cells. Neurochem Int. 2010;57(7):795-803.

82. Murugan A, Huse DA, Leibler S. Speed, dissipation, and error in kinetic proofreading. Proc Natl Acad Sci U S A. 2012;109(30):12034-9. doi:10.1073/ pnas.1119911109.

83. Cochella L, Green R. Fidelity in protein synthesis. Curr Biol. 2005;15(14):R536-40.

84. Belin S, Beghin A, Solano-Gonzàlez E, Bezin L, Brunet-Manquat S, Textoris J, Prats AC, Mertani HC, Dumontet C, Diaz JJ. Dysregulation of ribosome biogenesis and translational capacity is associated with tumor progression of human breast cancer cells. PLoS One. 2009;4(9):e7147.

85. Liu Y, Song C, Ni H, Jiao W, Gan W, Dong X, Liu J, Zhu L, Zhai $X, H u Z$, Li J. UBE2L3, a susceptibility gene that plays oncogenic role in hepatitis B-related hepatocellular carcinoma. J Viral Hepat. 2018;25(11):1363-1371.

86. Darvishian M, Janjua NZ, Chong M, Cook D, Samji H, Butt ZA, Yu A, Alvarez M, Yoshida E, Ramji A, Wong J, Woods R, Tyndall M, Krajden M. Estimating the impact of early hepatitis $\mathrm{C}$ virus clearance on hepatocellular carcinoma risk. J Viral Hepat. 2018;25(12):1481-1492.

87. Ye C, Zhang C, Huang H, Yang B, Xiao G, Kong D, Tian Q, Song Q, Song Y, Tan H, Wang Y, Zhou T, $Z i X$, Sun $Y$. The Natural Compound Myricetin Effectively Represses the Malignant Progression of 
Prostate Cancer by Inhibiting PIM1 and Disrupting the PIM1/CXCR4 Interaction. Cell Physiol Biochem. 2018;48(3):1230-1244.

\section{Контроль кількості і функціональності ізоформ еEF1A1 і еEF1A2 в клітинах ссавців}

\section{Б. С. Негруцький, О. В. Новосильна, Л. В. Порубльова, А. А. Вісловух}

Мета. Представити короткий огляд деяких механізмів, за допомогою яких клітини ссавців контролюють експресію і функціональність двох ізоформ фактора елонгації трансляції еEF1А. Результати. Описано клітинну тактику контроля білків еEF1A1 i еEF1A2 за участі пост-трансляційних модифікацій, білок-білкових та білок-РНКових взаємодій, а також регуляції кількості і стабільності EEF1A1 і EEF1A2 мРНК. Висновки. Рівень мРНК, що кодує еEF1A1 в ракових клітинах, може залежати від зміни кількості алельних копій, у той час, коли рівень EEF1A2 мРНК може контролюватися за допомогою мікро РНК. Активність білка еEF1A2 в різних клітинних процесах, може визначатися, зокрема, підвищеною, в порівнянні з еЕF1A1, афінністю до тРНК і вірусної РНК. В свою чергу, активність еEF1A1 може регулюватися підвищеною, в порівнянні 3 еF1A2, доступністю цього білка до пост-трансляційних модифікацій і білок-білкових взаємодій.

К л юч о в і с сло в а: Фактори елонгації трансляції, регуляція, білкові ізоформи.

\section{Контроль количества и функциональности изоформ еEF1A1 и еEF1A2 в клетках млекопитающих}

Б. С. Негруцький, О. В. Новосильна, Л. В. Порубльова, А. А. Вісловух

Цель. Представить краткий обзор некоторых механизмов, с помощью которых клетки млекопитающих контролируют экспрессию и функциональность двух изоформ фактора элонгации трансляции еEF1A. Результаты. Описано клеточную тактику контроля белков еEF1A1 і еEF1A2 с участием пост-трансляционных модификаций, белок-белковых и белок-РНКовых взаимодействий, а также регуляции количества и стабильности EEF1A1 і ЕEF1A2 мРНК. Выводы. Уровень мРНК, которая кодирует еЕF1А1 в раковых клетках, может определяться измененным количеством аллельных копий, в то время как уровень мРНК, кодирующей еEF1A2, может контролироваться посредством микроРНК. Активность белка еEF1А2 в разных клеточных процессах может определяться, в частности, его увеличенной, в сравнении с еEF1A1, аффинностью к тРНК и вирусной РНК. В свою очередь, активность eEF1A1 может регулироваться увеличенными, по сравнению с еEF1A2, подверженностью этого белка пост-трансляционным модификациям и доступностью для белок-белковых взаимодействий.

Ключевые слова: Факторы элонгации трансляции, регуляция, белковые изоформы.

Received 03.09.2018 